\title{
Mudflow hazard in the foothill and mountainous regions of Uzbekistan
}

\author{
I Dergacheva ${ }^{2}, S$ Klimov $^{2}, G$ Khamdamova $^{3}$, Qudratjon Raximov ${ }^{1 *}$ and Tursunoy \\ Apakhujayeva $^{1}$ \\ ${ }^{1}$ Tashkent Institute of Irrigation and Agricultural Mechanization Engineers, Tashkent, Republic of \\ Uzbekistan \\ ${ }^{2}$ Hydrometeorological Research Institute of Uzhydromet,72 1st Bodomzor yuli, Tashkent 100000 \\ ${ }^{3}$ Center of the Hydrometeorological Service of Republic of Uzbekistan 72 1st Bodomzor yuli, \\ Tashkent 100000.
}

\begin{abstract}
The article presents the results of research work on the study of mudflows in the territory of the Republic of Uzbekistan and transboundary territories. The relevance of studies of mudflow phenomena is determined by the intensive development of economic and recreational development of mountain and foothill territories, which in the conditions of the Republic of Uzbekistan are subject to mudflow processes that cause material damage to the objects of the national economy and are often accompanied by human casualties. About a thousand active mudflow channels have been counted in the study area, of which over 270 descend into the Fergana Valley. The most mudflow-prone regions in Uzbekistan are: Namangan - 19\% of all registered mudflows, Fergana - 16\%, Surkhandarya - 13\%, Tashkent $12 \%$, Kashkadarya - $11 \%$ and Samarkand - 9\%. In general, the Fergana Valley accounts for $41 \%$ of the total number of all registered mudflows. A sharp increase in mudflow activity is observed in April and May. During these months, respectively, $25 \%$ and $35 \%$ of mudflows descended. As a rule, these are mudflows that came down as a result of a large amount of precipitation. The most mudflow-prone regions in Uzbekistan are: Namangan - $19 \%$ of all registered mudflows, Fergana - 16\%, Surkhandarya - 13\%, Tashkent - 12\%, Kashkadarya - $11 \%$ and Samarkand - 9\%. In general, the Fergana Valley accounts for $41 \%$ of the total number of all registered mudflows.
\end{abstract}

\section{Introduction}

When people talk about mudflows, as a rule, the imagination of its phenomenon is very contradictory. In Central Asia, according to the concept of local residents, it is customary to call a mudflow of short-term high intensity precipitation (showers), as a result of the fallout of which a mass of small streams is formed, from the confluence of which powerful flows of enormous destructive force often arise. This last, which has already been transformed in the modern concept, is called mudflow.

\footnotetext{
*Corresponding author: q.raximov@ttiiame.uz
} 
Mudflows are mountain streams saturated with solid material that are formed in some basins mainly from rainfall [1].

Mudflow - is a natural disaster causing enormous damage to the national economy of many regions of our republic. Mudflows cause human casualties and death of livestock, destroy industrial facilities and residential buildings, hydraulic structures, bridges, roads, communication lines and power transmission lines, bring in agricultural fields and the irrigation network, destroy orchards, vineyards and crops.

The study of the engineering-geological conditions for the formation of mudflows, the state and properties of mudflow-forming rocks in the system of the Ministry of Geology of Uzbekistan began in 1964 by engineering-geological teams under the direct methodological guidance of VSEGINGEO and GIDROINGEO.

To understand the essence and regularities of the formation of mudflow centers, their relationship with the main types of mudflow formation mechanism, the nature of the development and transformation of mudflows, specialized engineering-geological and hydrogeological studies of individual regions of the republic and mountainous regions surrounding it were carried out.

The study covered large basins in the Fergana depression (Isfayram, Shakhimardan, Sokh, Sumsar, etc.), Chatkal and Kuramin ranges (Pskem, Ugam, etc.) [2].

A systematic study of mudflows in Uzbekistan was first organized in the southwestern spurs of the Gissar ridge in 1928. Mountain-mudflow parties were created (Fergana, Namangan, Kashkadarya, Surkhandarya). The mudflow regime of watercourses in the area was investigated by employees of hydrometeorological stations. In 1966-1968 V. A. Kudyshkin and V. A. Bondar carried out a regional study of mudflows. In 1972, Yu. N. Ivanov and VL Babko identified mudflow centers and flooding zones of the Kashkadarya region. At the end of the last century, NIGMI carried out a large number of works on the study of mudflow formation, the study of synoptic processes affecting mudflow, developments were carried out in the field of forecasting mudflow hazard [3-10]. All these developments formed the basis of the modern stage of research in the field of mudflow formation and the spread of mudflows in the territory of the Republic of Uzbekistan.

Studies carried out by international experts provide evidence of a close relationship between climate change and an increase in the frequency and intensity of dangerous hydrometeorological phenomena leading to climatic disasters, which justifies the need for a comprehensive study of mudflow phenomena in the main mudflow-prone areas located in the basins of mountain and foothill rivers. In recent decades, research in this area has been Priority attention is given, since the creation of early warning systems contributes to improving environmental safety, protecting the economy, population and vital human interests from the possible negative impact of dangerous hydrometeorological phenomena and is of particular relevance [11-18].

\section{Initial data and research methods}

When conducting research on mudflow phenomena, the main methods of obtaining information are expeditionary observations, route geomorphological mapping, as well as operational information coming from the Uzhydromet network. The materials of the Scientific Research Hydrometeorological Institute and the data of hydrometeorological observations of the Center of the Hydrometeorological Service of the Republic of Uzbekistan were used as the main initial information for this study. These materials are supplemented with data from expeditionary observations and field experimental materials used after their processing by conventional methods, including methods of mathematical statistics - correlation and multivariate analysis, an objective method of aligning and normalizing correlations. In the process of performing the work, the methods of 
cartographic research, comparative geographical, the method of geographical generalization and analogy were widely used.

\section{Main part}

Mudflows are widespread in the mountainous regions of Central Asia and South-East Kazakhstan, representing a characteristic feature of the regime of many rivers and temporary streams (Fig. 1). Information about them has been available since 1874 .

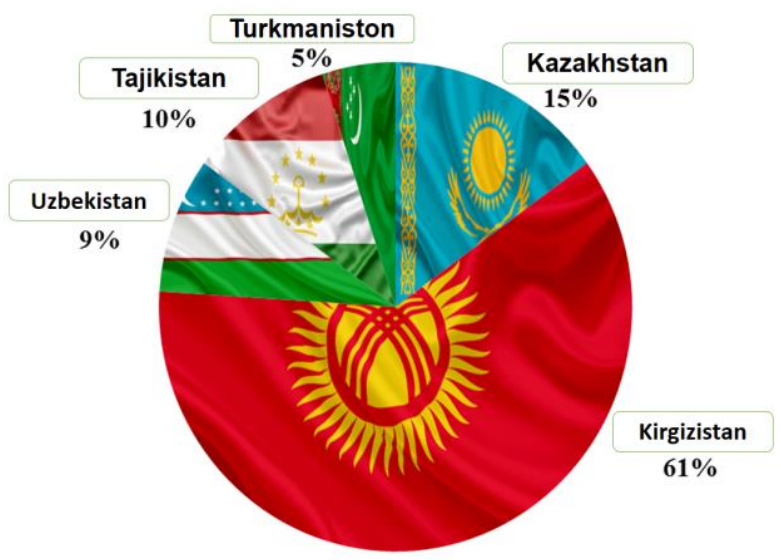

Fig. 1. Distribution of mudflow basins in the countries of Central Asia.

Mudflows were most developed in the Fergana and Issyk-Kul basins, southwestern regions of Uzbekistan, in the Tashkent oasis, the Nuratau mountains, the Zarafshan river basin, the northern and southwestern parts of Tajikistan, the mountains of Turkmenistan, the northern ridges of the Tien Shan, the Dzhungar Alatau, Saur -Tarbagatai and the Kazakhstan part of Altai. About a thousand active mudflow channels have been counted on this territory, of which more than 270 descend into the Fergana Valley. It is necessary to take into account the fact that many mountain territories within Kazakhstan and Central Asia are still far from insufficiently studied in terms of mudflows [15-17].

Mudflow basins, within the above territory, have catchment areas from a fraction of $\mathrm{km} 2$ to $100 \mathrm{~km} 2$ and more. Most of them (76\%) are up to $100 \mathrm{~km} 2$ (Fig. 2).

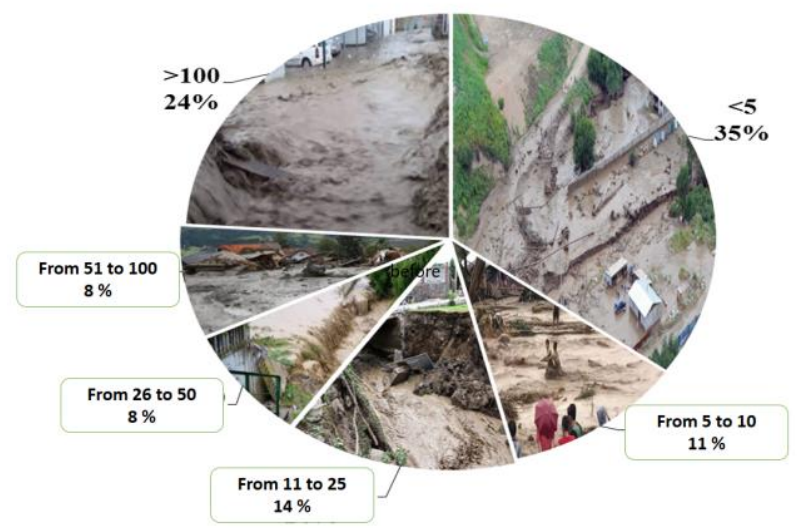

Fig. 2. Distribution of mudflow basins in Central Asia by size (km2). 
The main mudflow areas on the territory of the Republic of Uzbekistan are currently the following:

1 Fergana Valley with its mountainous framing (the southeastern slopes of the Kuramin and Chatkal ridges, the southern and southwestern Atoynak, the Isfanjailo, Baubashat ranges, the southwestern slopes of the Fergana, northern Alay and eastern parts of Turkestan, the Mogoltau ridge and the Utoynak). The Fergana Valley is a zone of the most active mudflow and, in general, can be considered as one of the most significant regions in Central Asia in terms of the development of mudflow processes. Almost all slopes (channels) descending to it are more or less mudflow hazardous, but among them there are areas of maximum development of mudflows, which include, first of all, the southeastern slopes of the Chatkal ridge, where in the basins of Padshaata, Kasansay and Gavasai about $40 \%$ of all mudflows in the Fergana Valley. Another mudflow area of Fergana is the northern slope of the Alay ridge (about 30\% of all mudflows). Here the most mudflowprone basins (from east to west) are Gulcha-Kurshab, Taldyk, Akbura, Aravan, Abshirsay, Isfairamsay, Shakhimardan, Sokh and others less significant. The northern slope of the Turkestan ridge (eastern part) is very active in mudflows - about $25 \%$ of all mudflows in Fergana. Most of them are formed in the basins of Isfana and others. Mudflows are often formed on temporary watercourses or in dry channels of the southeastern slopes of the Kuraminsky ridge and the Mogoltau mountains, where Chadaksay, Aktashsay, Pangaz, Karakhan, Karamazarsai stand out. Relatively fewer mudflows were noted in the eastern part of the Fergana Valley, where separate channels of the southwestern slopes of the Fergana ridge and the Baubashat mountains are mudflow-bearing. These are mainly the right tributaries of the Karadarya (Changet, Kurgantash, Kugart, Karaunkur, Shaidansai, Mailisu) and the lower reaches of the Naryn (Karasu and a number of small ones).[18-20]

2 Southwestern regions of Uzbekistan (northwestern and southeastern slopes of the Gissar ridge, southern slopes of the western part of Zarafshan and western slopes of the Baysuntau mountains). In this area (the second in terms of mudflow hazard after Fergana), the most mudflow hazardous are the right tributaries of the Surkhandarya and a number of tributaries of the Kashkadarya (basins of the Shirabad, Sangardak, Tupolanga, Dashnabad, Dzhynydarya, Aksu, Tankhazdarya, Yakkabagdarya, Lyangardarya, Lyangardarya). The ubiquitous distribution of fan fans in this area indicates a wide range of mudflow opportunities.

3 Mountains of Tashkent oasis (Karzhantau ridges, Ugamsky, Pskemsky, Sandalashsky and southwestern slopes of the Chatkal ridge). The Chirchik river basin is most muddy, especially in the middle and lower reaches, as well as the Chirchik-Akhangaran (Angren) interfluve, where the selenos are Sukoksay, Bashkyzylsay, Parkentsay, Zarkentsay, Altynbelsay, Aksakatasai, Karamazarsay, Karankulsay. The Akhangaran basin is less mudflow active, however, there are frequent cases of catastrophic mudflows. The main mudflow streams are located on the right bank within the low mountains (southern slopes of the Chatkal ridge). These are Yakkarcha, Toganbashisay, Dukantsay, Karabausay, Akchasay, Shavazsay. A number of mudflow channels descend from the northern slopes of the Kuraminsky ridge (Naugarzan, Nishbash, Shaugazsay, Almalyksay, Karakiyasay). The Tashkent group also includes mudflow streams of the Keles River basin and located on the southwestern slopes of the Kuraminsky ridge (Sordobsay, Utkansai).[21,22]

4 Mountains of the western part of Uzbekistan (Nuratau, Karatau, Aktau, Malguzar). Here, mainly the sais of the southwestern slopes of Nuratau and southern Karatau are dangerous, where Saganaksay, Sagishmansay, Kattasay (Karasu basin), Tusun, Akbarsai, Sabistan, Tasmachisai, Maidan, Aktepa, Kuchkarsay, Uischansi and others, Aktivny, Sarmysai and others originate. Zerabulak Upland (Dzhenichka, Shauvazsay, Yarkuduk, Kyzylsay, Tashmechetsay, etc.). 
5 Valley of the Zarafshan River (southern slopes of the western part of the Turkestan ridge, northern and southwestern - Zarafshan, northern - Gissar with its western spurs). The main mudflow streams are located in the middle and lower parts of the basin. The most muddy-ridden is the northern slope of the Zarafshan ridge (middle reaches of the Zarafshan), where the basins of the Fandarya, Kshtut, Magiandarya and a number of sais (Madm, Vashan, Zavron, Chinorsay, Saursay, Zebonsai) are distinguished. A number of mudflow channels exist in the Kshtut-Fandarya interfluve (left bank). On the right bank of the selenose forest there are Obikrut, Duoba and several nameless sais. In the upper part of the basin, the southern slopes of the Zarafshan Range, where there are a number of mudflow streams, are prone to mudflow. In the lower part (northern and southwestern slopes of the Zarafshan ridge), Urgut, Tersaksay, Ayakchidarya, Gavkhonasay, Kalkamassay, Kuruksay, Taragaysay, Lyangar, Tolokolsay, Kiyakulisay, Sazagansay, Aksaiysh, as well as the Saai Uplands belong to the seleniferous ones. The Zerafshan basin sometimes also includes selenium-bearing watercourses in the Sanzar and Zaaminsu basins, as well as those located in this interfluve (Achisay, Karamazarsay, Pshagarsay, Kuzhapishkent, and a number of others). In the Sanzar and Zaaminsu basins, mudflows occur on the northern slopes of the Turkestan ridge and, less often, on the western ones.

Mudflows are mainly formed in the basins of the Surkhandarya river in March - June with a maximum in April and the Kashkadarya river in April - May with a maximum in April due to rainfall, intense snow melting and heavy rains.

Also in April, the maximum mudflow activity occurs in the Samarkand and Tashkent regions. In May, there is a peak in Namangan, Fergana, Andijan, Jizzakh, Syrdarya and Navoi regions (Table 1). In general, in Uzbekistan, the maximum number of mudflows occurs in May (Fig. 3).

In connection with the enormous potential danger of mudflows, it becomes necessary to assess the possible risk to people. Risk is understood as the possibility of undesirable consequences from any action or undesirable course of events. There are two categories of risk. One category characterizes the risk to human life and is defined as the number of victims per unit of time. Another category is related to material damage and is measured by cost indicators per unit of time.

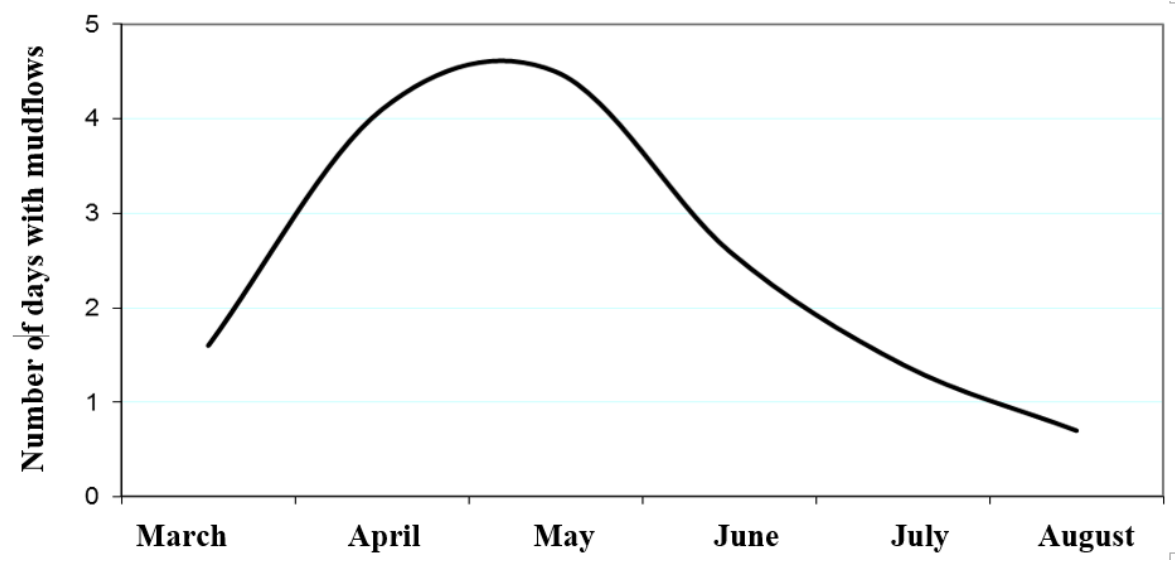

Fig. 3. Intra-annual distribution of the number of days with mudflows in Uzbekistan. 
Table 1. Number of days with mudflows on the territory of Uzbekistan for the observation period from 1987 to 2020 .

\begin{tabular}{|l|c|c|c|c|c|c|c|}
\hline \multirow{2}{*}{ Region } & \multicolumn{7}{|c|}{ Month } \\
\cline { 2 - 9 } & III & IV & V & VI & VII & VIII & Total \\
\hline Namangan & 1 & 12 & 51 & 25 & 11 & 1 & 101 \\
\hline Fergana & & 11 & 26 & 19 & 10 & 7 & 73 \\
\hline Andijan & 7 & 27 & 21 & 4 & 1 & 1 & 61 \\
\hline Tashkent & 11 & 21 & 17 & 7 & 1 & & 57 \\
\hline Samarkand & 1 & 11 & 14 & 8 & 2 & 1 & 37 \\
\hline Djizakh & 5 & 31 & 13 & 4 & 2 & 5 & 60 \\
\hline Kashkadarya & 1 & 9 & 5 & 1 & & & 16 \\
\hline Navai & 6 & 25 & 19 & 3 & 1 & 3 & 57 \\
\hline Surkhandarya & & 1 & 13 & 2 & 2 & & 18 \\
\hline Sirdarya & 32 & 159 & 198 & 77 & 31 & 18 & 515 \\
\hline Uzbekistan & & & & & & & \\
\hline
\end{tabular}

Mudflow events in Uzbekistan are accounted on the basis of "information about past mudflows", where the mudflow is recorded simply as a spontaneous phenomenon, without taking into account the flow rate and flow rate, and is characterized by two gradations: OY - a dangerous phenomenon that causes material damage, and OHL - spontaneous a hydrometeorological phenomenon accompanied by human casualties (Table 2).

Table 2. Distribution of the number of mudflows with different magnitudes of damage inflicted by regions of Uzbekistan, \%

\begin{tabular}{|l|c|c|}
\hline \multicolumn{1}{|c|}{ Region } & OL & OHL \\
\hline Namangan & 45 & 18 \\
\hline Fergana & 42 & 16 \\
\hline Andijan & 37 & 21 \\
\hline Samarkand & 48 & 17 \\
\hline Kashkadarya & 41 & 13 \\
\hline Tashkent & 55 & 9 \\
\hline Djizakh & 62 & 5 \\
\hline Navoiy & 50 & 20 \\
\hline
\end{tabular}

In total, $19 \%$ of the territories that are mudflow hazardous have been identified in Uzbekistan, which are subdivided into 4 categories of mudflow hazard with mudflow flow rates from 10 to $500 \mathrm{~m} 3 / \mathrm{s}$ and more: 
I category - with mudflow discharge over $500 \mathrm{~m}^{3} / \mathrm{s}$;

II category - with discharge from 100 till $500 \mathrm{~m}^{3} / \mathrm{s}$;

III category - with discharge less than $100 \mathrm{~m}^{3} / \mathrm{s}$;

IV category - with discharge of $10 \mathrm{~m}^{3} / \mathrm{s}$.

96 settlements of our republic are located in the territories under the II, III and IV categories of mudflow hazard. In Kashkadarya region, 3 settlements are located in the zone of the 1 st category of mudflow hazard with a possible discharge more than $500 \mathrm{~m} 3 / \mathrm{s}$.

\section{Conclusion}

Analysis of materials on mudflows and mudflow activity showed that mudflows of all types are observed in Uzbekistan, but mudflows caused by heavy rainfall dominate $(85 \%$ of the total number of registered mudflows).

Mudflows of this type occur during intense and prolonged precipitation. Mudflow activity in Uzbekistan manifests itself mainly in the period from March to August. In some years, the first mudflows are possible in February. A sharp increase in mudflow activity is observed in April and May. During these months, respectively, 25\% and 35\% of mudflows descended.

As a rule, these are mudflows that came down as a result of a large amount of precipitation. The most mudflow-prone regions in Uzbekistan are Namangan - $19 \%$ of all registered mudflows, Fergana - 16\%, Surkhandarya - 13\%, Tashkent - 12\%, Kashkadarya $11 \%$ and Samarkand $-9 \%$. In general, the Fergana Valley accounts for $41 \%$ of the total number of all registered mudflows.

\section{References}

1. Fleishman S.M. Mudflow. -L .: Gidrometeoizdat, 1978. - S. 16-48.

2. Rauschenbakh I.O. About the distribution of mudflows in the territory of Central Asia and Kazakhstan. // Issues of studying mudflows // Proceedings of KazNIGMI. - M .: Hydrometeoizdat, 1969. - Issue. 33 .-- S. 131.

3. Arifzhanov, A.M. Method for calculation of the distribution of drift particles in variable section beds (VSB) (2004) Gidrotekhnicheskoe Stroitel'stvo, (2), pp. 44-45.

4. Arifzhanov, A.M. Distribution of Suspended Sediment Particles in a Steady-State Flow. (2001) Water Resources, 28 (2), pp. 164-166. DOI: 10.1023/A:1010375500148

5. Kirenskaya T.L., Danilina N.A. On long-term forecasts of mudflow phenomena of storm origin // Mudflows. - M., Hydrometeorological Publishing House, 1989. - Sat. 11. - P. 27.

6. Lyakhovskaya L.F. Mudflow hazard in the foothills of Uzbekistan and its short-term forecast: Author's abstract. dis. ... Cand. geogr. Sciences: 11.00.07. - T., 1989 .-- 42 p.

7. Methodical guidelines // Method of short-term forecast of mudflow hazard in the foothills of the Tashkent region. - T., SANIGMI, 1995 - $47 \mathrm{p}$.

8. Arifjanov, A., Rakhimov, K., Abduraimova, D., Babaev, A., Melikuziyev, S. Hydrotransport of river sediments in hydroelelators. (2020) IOP Conference Series: Materials Science and Engineering, 869 (7). DOI: 10.1088/1757-899X/869/7/072003

9. Arifjanov, A., Rakhimov, K., Abduraimova, D., Akmalov, S. Transportation of river sediments in cylindrical pipeline (2019) IOP Conference Series: Earth and Environmental Science, 403 (1). DOI: 10.1088/1755-1315/403/1/012154 
10. Arifjanov, A., Apakhodjaeva, T., Akmalov, S. Calculation of losses for transpiration in water reservoirs with using new computer technologies. (2019) International Conference on Information Science and Communications Technologies: Applications, Trends and Opportunities, ICISCT 2019. DOI: 10.1109/ICISCT47635.2019.9011883

11. Arifjanov, A., Otaxonov, M., Samiev, L., Akmalov, S. Hydraulic calculation of horizontal open drainages (2019) E3S Web of Conferences, 97. DOI: $10.1051 / \mathrm{e} 3$ sconf/20199705039

12. Mudflows of Uzbekistan. T., Administration of the Hydrometeorological Service of Uzbekistan, 1965. - 33-37 p.

13. Dergacheva I.V. Flash floods caused by the breakthrough of high-mountain lakes on the territory of Uzbekistan // European science review. - Austria, Vienna. No. 9-10. 2018. - R. 75-78

14. Dergacheva I.V., Klimov S.I. Hazardous hydrometeorological phenomena in Uzbekistan in the context of climate change // International scientific conference with elements of the scientific school "Innovative methods and research tools in the field of atmospheric physics, hydrometeorology, ecology and climate change." - Stavropol, 2003. -S. 222-225.

15. Abduraimova, D., Atakulov, D., Ibragimova, Z., Apakhodjaeva, T. Evaluation of erosion and accumulative process with using Geoinformation systems in water resource management (2019) International Conference on Information Science and Communications Technologies: Applications, Trends and Opportunities, ICISCT 2019. DOI: 10.1109/ICISCT47635.2019.9012020

16. Fatxulloyev, A., Gafarova, A., Otakhonov, M., Allayorov, D. The hydraulic efficiency of the soil channels. IOP Conference Series: Materials Science and Engineering, 2020, 883(1), 012042 doi:10.1088/1757-899X/883/1/012042

17. Myagkov S.V., Myagkov S.S., Dergacheva I.V. Mudflows in Central Asia // Sel-toshki va kuchki khodisalari bilan, Ministry of Emergencies, Tashkent, 2019, pp. 31-34.

18. Myagkov S.V., Khalbekov K., Dergacheva I.V. Mathematical modeling of floods in the city as a result of heavy rainfall // Science and innovative development, no. 3, 2019 , p. 85-89

19. S.I. Klimov, I.V. Nazarova, I.V. Dergacheva, S.V. Myagkov, Yu.A. Plotnitskaya Values for Uzbekistan monitoring of hazardous phenomena associated with the water factor // Republican scientific and practical conference "Problems of providing rural settlements with water resources in dry years and measures for their solution." Tashkent, 2008. -P. 114-116.

20. Khikmatov B.F., Dergacheva I.V., Khikmatov F.Kh., Starovatov A.A. Calculation of the hydrograph of the breakthrough of high mountain lakes in Uzbekistan (Examples of Ihnach-large lake) // TEST Engineering and Management, Volume 83, March - April 2020. ISSN: 0193-4120 Page No. 8508 - 8515.

21. Rakhimov, Q., Allayorov, D., Ibragimova, Z. Increasing flow turbidity in pressure systems. (2020) IOP Conference Series: Materials Science and Engineering, 869 (7). DOI: $10.1088 / 1757-899 X / 869 / 7 / 072029$

22. Rakhimov, K., Ahmedkhodjaeva, Xoshimov, S. Theoretical bases of hydraulic mixture in round cylindrical pipelines (2020) IOP Conference Series: Earth and Environmental Science, 614 (1). DOI: 10.1088/1755-1315/614/1/012095 